\title{
Review on The Expected Role of Climate Smart Agriculture on Food System in Ethiopia
}

\author{
Bikila Tesfa Kebeda $^{1 *}$, Temesgen Olani Abdisa ${ }^{1}$ and Abera Jaleta Berkessa ${ }^{2}$ \\ ${ }^{1}$ Department of Agricultural Economics, Ethiopia \\ ${ }^{2}$ Department of Horticulture, Ethiopia
}

*Corresponding author: Bikila Tesfa Kebeda, Department of Agricultural Economics, Bedele College of Agriculture and Forestry, Mettu University, Ethiopia.

Received Date: June 24, 2019

Published Date: July 09, 2019

\begin{abstract}
This paper reviews various articles, reports and documents on expected role of climate smart agriculture on food system and factors affecting its adoption in Ethiopia. Climate change is global phenomena and is already negatively impacting agricultural production globally and locally. Climate risks to cropping, livestock and fisheries are expected to increase in coming decades, particularly in low-income countries where adaptive capacity is weaker. By 2030,90\% of the world's major crops, including maize, rice and wheat, will experience reduced or stagnant growth rates as a result of climate change. Climate change is expected to have a greater impact in low-income countries such as Ethiopia because of low numbers of trained people, poor infrastructures and limited economic capability to respond to the challenges. Developing countries such as Ethiopia are less capable of mitigating or adapting to the changes due to their poverty and high dependence on the environment for subsistence. The mainstay of the Ethiopian economy is rain fed agriculture, which is heavily sensitive to climate variability and change. So, this climate change risks require changes in agricultural technologies and approaches to improve the lives of those still locked in food insecurity and poverty and to prevent the loss of gains already achieved. To achieve food security and agricultural development goals, adaptation to climate change will be necessary. Climate-smart agriculture (CSA) is an integrative approach to address the interlinked challenges of food security and climate change. CSA practices in Ethiopia includes proven practical techniques such as mulching, intercropping, conservation agriculture, crop rotation, integrated crop-livestock management, agroforestry, improved grazing and improved water management. CSA has great role in improving food system by addressing food security, reducing poverty and addressing the relationship between climate change and agriculture. Access to information, access to finance and insurance, access to Agricultural input and access to Credit service are some factors that affecting Adoption of CSA. Therefore climate-smart agriculture is essential approach that farmers are supported to adopt to sustain their livelihoods.
\end{abstract}

Keywords: Climate smart agriculture; Climate change; Ethiopia

\section{Introduction}

\section{Background}

Agriculture is the most important economic sector of many developing countries and is a proven path to prosperity. No region of the world has developed a diverse, modern economy without first establishing a successful foundation in agriculture [1]. Agricultural production systems are expected to produce food for a global population that will amount to 9.1 billion people in 2050 and over 10 billion by end of the century (UNFPA 2011). Agriculture forms a significant portion of the economies of all African countries, as a sector it can therefore contribute towards major continental priorities, such as eradicating poverty and hunger, boosting intra-Africa trade and investments, rapid industrialization and economic diversification, sustainable resource and environmental management, and creating jobs, human security and shared prosperity [1].

SSA is generally regarded as land abundant and there is high potential agricultural production [2]. Agriculture is central to the survival of millions of people in many countries of sub-Saharan Africa (SSA). It is the number one provider of employment and livelihood in developing countries [3].

Agriculture has always been the backbone of the Ethiopian economy. Agriculture in Ethiopia includes crops, livestock, forestry, fisheries and apiculture. It is the most important sector of the national economy and the main source of livelihoods for 85 percent of the population [4]. However, Agriculture in sub-Saharan Africa (SSA) is vulnerable to climate variability. Scientific evidence shows 
that climate variability will substantially affect food security for the poor in SSA (Maurel and Kubik 2014; Zewdie 2014). Predictions by the Intergovernmental Panel on Climate Change (IPCC), for example, have indicated that climate change and variability could reduce yields and income from agriculture in SSA by $50 \%$ and $90 \%$ in 2020 and 2100, respectively [5]. Average yields of maize, wheat, and rice have been predicted to decrease by $14 \%, 22 \%$, and $5 \%$, respectively, by 2050 in SSA, while the yields of sorghum, millet, and groundnuts are also expected to decline by $27-32 \%$ [4].

In Ethiopia Smallholder agricultural production remains low, particularly for cereal crops, which is attributed to erratic and unreliable rainfall and the failure of current agricultural techniques to mitigate such conditions; inefficient use by farmers of agricultural resources such as soil amendments; and rainwater that contributes to soil degradation. Other contributory factors include limited use of improved seed and fertilizers and inadequately resourced agricultural extension systems. Moreover, the dry lowlands experience erratic rainfall at times with very severe droughts, the impact of which, together with land degradation, human population growth and climate change, has greatly impaired the country's economic and social development and its food security status [4]. In order to secure and maintain food security agricultural systems need to be transformed to increase the productive capacity and stability of smallholder agricultural production. The new paradigm

Table 1: Summary of some common CSA practices in Ethiopia.

\begin{tabular}{|c|c|c|}
\hline CSA Practice & Components & Why it is Climate Smart? \\
\hline Conservation Agriculture & $\begin{array}{l}\text { 1. Reduced tillage } \\
\text { 2. Crop residue management-mulching, intercropping } \\
\text { 3. Crop rotation/intercropping with cereals and legumes }\end{array}$ & $\begin{array}{l}\text { 1. Carbon sequestration } \\
\text { 2. Reduce existing emissions } \\
\text { 3. Resilience to dry and hot spells }\end{array}$ \\
\hline $\begin{array}{l}\text { Integrated Soil Fertility } \\
\text { Management }\end{array}$ & $\begin{array}{l}\text { 1. Compost and manure management, including green manur- } \\
\text { ing } \\
\begin{array}{l}\text { 2. Efficient fertilizer application techniques (time, method, } \\
\text { amount) }\end{array}\end{array}$ & $\begin{array}{l}\text { 1. Reduced emission of nitrous oxide and } \mathrm{CH}_{4} \\
\text { 2. Improved soil productivity }\end{array}$ \\
\hline Small-Scale Irrigation & $\begin{array}{l}\text { 1. Year-round cropping } \\
\text { 2. Efficient water utilization }\end{array}$ & $\begin{array}{l}\text { 1. Creating carbon sink } \\
\text { 2. Improved yields } \\
\text { 3. Improved food security }\end{array}$ \\
\hline Agroforestry & $\begin{array}{l}\text { 1. Tree-based conservation agriculture } \\
\text { 2. Practiced both traditionally and as improved practice } \\
\text { 3. Farmer managed natural regeneration }\end{array}$ & $\begin{array}{l}\text { 1. Trees store large quantities of } \mathrm{CO}_{2} \\
\text { 2. Can support resilience and improved productivity of } \\
\text { agriculture }\end{array}$ \\
\hline Crop Diversification & $\begin{array}{l}\text { 1. Popularization of new crops and crop varieties } \\
\text { 2. Pest resistance, high yielding, tolerant to drought, short } \\
\text { season }\end{array}$ & $\begin{array}{l}\text { 1. Ensuring food security } \\
\text { 2. Resilience to weather variability } \\
\text { 3. Alternative livelihoods and improved incomes }\end{array}$ \\
\hline $\begin{array}{l}\text { Improved Livestock Feed } \\
\text { and Feeding Practices }\end{array}$ & $\begin{array}{l}\text { 1. Reduced open grazing/zero grazing } \\
\text { 2. Forage development and rangeland management } \\
\text { 3. Feed improvement } \\
\text { 4. Livestock breed } \\
\text { 5. improvement and diversification }\end{array}$ & $\begin{array}{l}\text { 1. Improved livestock productivity } \\
\text { 2. GHG reduction } \\
\text { 3. } \mathrm{CH}_{4} \text { reduction }\end{array}$ \\
\hline Other & $\begin{array}{l}\text { 1. In situ water conservation/harvesting } \\
\text { 2. Early warning systems and improved weather information } \\
\text { 3. Support to alternative energy fuel efficient stoves, biofuels } \\
\text { 4. Crop and livestock insurance } \\
\text { 5. Livelihoods diversification (apiculture, aquaculture) } \\
\text { 6. Post-harvest technologies (agro processing, storage) }\end{array}$ & $\begin{array}{l}\text { 1. Resilience of agriculture } \\
\text { 2. Improved incomes } \\
\text { 3. Reduced emissions } \\
\text { 4. Reduced deforestation } \\
\text { 5. Reduced climate risk }\end{array}$ \\
\hline
\end{tabular}

Source: Jirata et al, [4]

\section{General objective}

To review climate smart agriculture and its expected role in improving food system in Ethiopia which is Climate Smart Agriculture is the key to strengthen the farmer's income and sustain food security. Climate-smart agriculture (CSA) is an approach for transforming and reorienting agricultural systems to support food security under the new realities of climate change [6].

Managing climate variability will help to reduce vulnerability and pave the way for adaptation to climate change. Climate information and policies are very fundamental to deal with the impacts of climate variability and change on development and resource management problems. A climate-smart agriculture (CSA) production system would consider understanding systems and clients to enhance institutional capacity for the implementation and up scaling of CSA practices and approaches [4]. CSA practices in Ethiopia includes proven practical techniques such as mulching, intercropping, conservation agriculture, crop rotation, integrated crop-livestock management, agroforestry, improved grazing and improved water management. CSA also involves innovative practices such as improved weather forecasting, early-warning systems and climate-risk insurance. CSA aims to get existing technologies off the shelf and into the hands of farmers, as well as to develop new technologies such as drought-tolerant or floodtolerant crops to meet the demands of the changing climate [4]. The table below shows some major CSA practices in Ethiopia (Table 1). 
Review on Climate Smart Agriculture and Its Expected Role in Improving Food System in Ethiopia

\section{Concepts of climate smart agriculture:}

Climate-smart agriculture (CSA), as defined and presented by FAO at the Hague Conference on Agriculture, Food Security and Climate Change in 2010, contributes to the achievement of sustainable development goals. It integrates the three dimensions of sustainable development (economic, social and environmental) by jointly addressing food security and climate challenges [7]. It is composed of three main pillars:

- $\quad$ Sustainably increasing agricultural productivity and incomes;

- Adapting and building resilience to climate change;

- $\quad$ Reducing and/or removing greenhouse gases emissions, where possible.

CSA is an approach to developing the technical, policy and investment conditions to achieve sustainable agricultural development for food security under climate change. The magnitude, immediacy and broad scope of the effects of climate change on agricultural systems create a compelling need to ensure comprehensive integration of these effects into national agricultural planning, investments and programs. The CSA approach is designed to identify and operationalize sustainable agricultural development within the explicit parameters of climate change (FAO 2013). FAO and its partners are aware that achieving the transformations required for CSA and meeting these multiple objectives requires an integrated approach that is responsive to specific local conditions. Coordination across agricultural sectors (e.g. crops, livestock, forestry and fisheries) as well as other sectors, such as with energy and water sector development is essential to capitalize on potential synergies, reduce trade-offs and optimize the use of natural resources and ecosystem services [4]. This approach also aims to strengthen livelihoods and food security, especially of smallholders, by improving the management and use of natural resources and adopting appropriate methods and technologies for the production, processing and marketing of agricultural goods. To maximize the benefits and minimize the tradeoffs, CSA takes into consideration the social, economic, and environmental context where it will be applied. Repercussions on energy and local resources are also assessed. A key component is the integrated landscape approach that follows the principles of ecosystem management and sustainable land and water use (FAO 2013).

As addressed by FAO, CSA is not a single specific agricultural technology or practice that can be universally applied. It is an approach that requires site-specific assessments to identify suitable agricultural production technologies and practices [4]. This approach:

- $\quad$ addresses the complex interrelated challenges of food security, development and climate change, and identifies integrated options that create synergies and benefits and reduce trade-offs;
- $\quad$ recognizes that these options will be shaped by specific country contexts and capacities and by the particular social, economic, and environmental situation where it will be applied;

- $\quad$ assesses the interactions between sectors and the needs of different involved stakeholders;

- identifies barriers to adoption, especially among farmers, and provides appropriate solutions in terms of policies, strategies, actions and incentives;

- $\quad$ seeks to create enabling environments through a greater alignment of policies, financial investments and institutional arrangements;

- strives to achieve multiple objectives with the understanding that priorities need to be set, and collective decisions made on different benefits and trade-offs;

- should prioritize the strengthening of livelihoods, especially those of smallholders, by improving access to services, knowledge, resources (including genetic resources), financial products and markets;

- addresses adaptation and builds resilience to shocks, especially those related to climate change, as the magnitude of the impacts of climate change has major implications for agricultural and rural development;

- Considers climate change mitigation as a potential secondary co-benefit, especially in low-income, agriculturalbased populations;

- $\quad$ Seeks to identify opportunities to access climate-related financing and integrate it with traditional sources of agricultural investment finance.

In General, Agriculture has to address simultaneously three intertwined challenges: ensuring food security through increased productivity and income, adapting to climate change and contributing to climate change mitigation [8]. Addressing these challenges, exacerbating global pressure on natural resources, especially water, will require radical changes in our food systems. To address these three intertwined challenges, food systems have to become, at the same time, more efficient and resilient, at every scale from the farm to the global level. They have to become more efficient in resource use (use less land, water, and inputs to produce more food sustainably) and become more resilient to changes and shocks.

CSA approach is an approach that requires site-specific assessments to identify suitable agricultural production technologies and practices [4].

\section{The analytical framework for climate-smart agriculture}

Climate-smart agriculture and development: Climate-smart agriculture (CSA) addresses the challenges of building synergies among climate change mitigation, adaptation and food security which are closely related within agriculture and minimizing their potential negative trade-offs. CSA seeks to enhance the capacity 
of the agriculture sector to sustainably support food security, incorporating the need for adaptation and the potential for mitigation into development strategies. The specific conditions, circumstances, and capacities within countries will define opportunities and barriers to implementation, and hence policy choices [9].

CSA builds on existing efforts to achieve sustainable agriculture intensification such as SCPI - Sustainable Crop Production Intensification (FAO 2001d). CSA will: (i) sustainably intensify production systems to achieve productivity increases thereby supporting the achievement of national food security and developmentgoals; (ii) increase the resilience of production systems and rural livelihoods (adaptation); and (iii) reduce agriculture's GHG emissions (including through increased production efficiency) and increase carbon sequestration (mitigation). There is no blueprint for CSA and the specific contexts of countries and communities would need to shape how it is ultimately implemented. Climatesmart agricultural production technologies are therefore aimed at maximizing food security benefits and, at the same time, can deliver significant climate change mitigation and adaptation co-benefits [10].

The definition of food security, adopted by the World Food Summit in 1996, highlights the multifaceted nature of the concept: "Food security, at the individual, household, national, regional and global levels [is achieved] when all people, at all times, have physical and economic access to sufficient, safe and nutritious food to meet their dietary needs and food preferences for an active and healthy life [11]". This definition captures the four dimensions of food security: availability, access, utilization and stability [12]. We define as "climate-smart" technologies which deliver multiple benefits specifically, food security and development benefits together with climate change adaptation and mitigation co-benefits.

Climate change adaptation: Adaptation is defined as activities that aim "to reduce the vulnerability of human or natural systems to the impacts of climate change and climate-related risks, by maintaining or increasing adaptive capacity and resilience [13]". The vulnerability of a system depends on its exposure and sensitivity to changes, and on its ability to manage these changes [14]. Vulnerability could be reduced by altering exposure, reducing sensitivity, and improving the adaptive capacity of the system $[15,16]$. IPCC [17] defines adaptive capacity as the ability or potential of a human or natural system to respond successfully to climate variability and change so as to moderate potential risks or cope with consequences of extreme events (floods, heavy hail/ snow events, heavy wind and dust storms, droughts and dry spells, heat waves and warm spells, cold spells). Among the main determinants of adaptive capacity are financial resources, technology, access to information and skills, infrastructure, social institutions and policies and equity [18]. Adaptation strategies and measures increase the range of climate conditions farmers can cope with. These could include a specific action (e.g. switching from one crop variety to another) or a systemic change (e.g. diversifying livelihoods against risks or an institutional reform to create incentives for better resource management) [19].

Economic development is a central element of adaptation to climate change, and the best way to reduce vulnerability to (current and future) climate events is often through basic development [11]. Overlaps in fact exist between 'development as usual' and adaptation activities [20], and different categories of activities are identified within the adaptation-development continuum [21,22], ranging from interventions aimed at increasing coping capacity that resemble pure development activities to explicit adaptation measures which may either be a response to extreme events or represent a slow onset climate change adaptation process.

Mitigation: Mitigation is defined as activities that contribute "to the objective of stabilization of greenhouse gas (GHG) concentrations in the atmosphere at a level that would prevent dangerous anthropogenic interference with the climate system by promoting efforts to reduce or limit GHG emissions or to enhance GHG sequestration [13]", including "technological changes that reduce resource inputs and emissions per unit of output" [3,23]. Agriculture is an important source of GHG emissions, representing 14 percent of the global total [24]. If related land-use change, including deforestation (for which agriculture is a key driver) and emissions beyond the farm gate are considered, the sector's share would be higher.

There is substantial mitigation potential in the agriculture sector: the technical mitigation potential of agriculture by 2030 , considering all GHGs, is estimated to be between 4,500 [25] and 6,000 Mt CO2e/year [26] and 70 percent of this potential could be realized in developing countries [27]. This potential could be achieved in some cases through absolute reductions in GHG emissions - including removal through sequestration in agricultural soils, and below and above ground biomass - and through greater efficiency in agricultural production, therefore leading to fewer emissions per unit of product [28]. In general climate smart agriculture (CSA) can be defined as "agriculture that sustainably increases agricultural productivity, enhances resilience (adaptation) [of agricultural and food security systems to climate change at multiple levels], reduces/removes greenhouse gas/GHGs (mitigation) where possible, and enhances achievement of national food security and development goals [29]". In this definition, the principal goal of CSA is identified as food security and sustainable agriculture development (including crops, livestock and fisheries). Productivity, adaptation, and mitigation are identified as three interlinked pillars necessary to achieve this goal while aiming at reducing/removing GHG emissions and tackling the new challenges of climate change [29].

\section{Expected role of CSA in improving food system}

CSA addresses food security, misdistribution and malnutrition: Despite the attention paid to agricultural development and food security over the past decades, there are still about 800 million undernourished and 1 billion malnourished 
people in the world. At the same time, more than 1.4 billion adults are overweight and one third of all food produced is wasted. Before 2050, the global population is expected to swell to more than 9.7 billion people [30]. At the same time, global food consumption trends are changing drastically, for example, increasing affluence is driving demand for meat-rich diets. If the current trends in consumption patterns and food waste continue, it is estimated we will require $60 \%$ more food production by 2050 [8]. CSA helps to improve food security for the poor and marginalized groups while also reducing food waste globally [31].

CSA addresses the relationship between agriculture and poverty: Agriculture can help to reduce poverty, raise incomes and improve food security for $80 \%$ of the world's poor, who live in rural areas and work mainly in farming [32]. Agriculture continues to be the main source of food, employment and income for many people living in developing countries. Indeed, it is estimated that about $75 \%$ of the world's poor live in rural areas, with agriculture being their most important income source [6]. As such, agriculture is uniquely placed to propel people out of poverty. Agricultural growth is often the most effective and equitable strategy for both reducing poverty and increasing food security [29].

CSA addresses the relation between climate change and agriculture: Climate change is already increasing average temperatures around the globe and, in the future, temperatures are projected to be not only hotter but more volatile too. This, in turn, will alter how much precipitation falls, where and when. Combined, these changes will increase the frequency and intensity of extreme weather events such as hurricanes, floods, heat waves, snowstorms and droughts. They may cause sea level rise and salinization, as well as perturbations across entire ecosystems. All of these changes will have profound impacts on agriculture, forestry and fisheries (FAO 2013a).

The agriculture sector is particularly vulnerable to climate change because different crops and animals thrive in different conditions. This makes agriculture highly dependent on consistent temperature ranges and water availability, which are exactly what climate change threatens to undermine. In addition, plant pests and diseases will likely increase in incidence and spread into new territories [33], bringing further challenges for agricultural productivity. While climate change will have both positive and negative impacts on crop yields - meaning that for some crops in some areas, yields will rise while others elsewhere suffer - negative impacts have outweighed positive impacts to date [34]. Already, it is estimated that climate change has reduced global yields of wheat by $5.5 \%$ and of maize by $3.8 \%$ [35].

By 2090, it is projected that climate change will result in an $8-24 \%$ loss of total global caloric production from maize, soy, wheat and rice. Where these declines in productivity occur will vary. For example, sub-Saharan Africa will be hit particular hard; it is estimated that across Africa maize yields will drop by $5 \%$ and wheat yields by $17 \%$ before 2050 [36].
As identified by different institutions and researchers some expected roles of CSA are: -

- Addresses food security, misdistribution and malnutrition

- Addresses the relationship between agriculture and poverty

- Decreases food insecurity.

\section{Factors affecting adoption of CSA}

Large numbers of empirical researches have been conducted over the years to understand factors that affect farmer adoption of Climate Smart Agriculture (Teklewold et al., 2013; Wollni et al., 2010; Nyong et al., 2007).

Effects of information on adoption of CSA: Information on the types of options, particularly those well suited to local conditions, is often scarce. For example, this lack of information can increase the risk of planting expensive seeds that may not survive or otherwise do poorly [37]. Information available to farmers on the types of CSA options that are well-adapted to the locality is likely to be an important determinant for adoption. Information may come from a number of sources, including government extension programmes and non-governmental organization (NGO)/donor programmes [38].

Climate change, by increasing uncertainty, as well as the value of rapid and accurate response (or the costs of not doing so) increases the value of information [28]. These include institutions engaged in agricultural research, extension, agricultural production and marketing statistics and the provision of climate-related information. Adopting CSA requires farmers to make both short- and long-term planning decisions and technology choices. Agricultural extension systems are the main conduit for disseminating information required to make such changes. Yet, problems with delivering information at a relevant spatial and time scale, difficulty in communicating the information and lack of user participation in development of information systems are all problems that have been encountered [39].

Effects of finance and insurance on adoption of CSA: Adopting CSA options implies a need for increased, as well as extended, investments at the farm level. McCarthy et al. [40] document the extended transition times needed to realize the benefits to CSA in the form of productivity or increased resilience. During the transition, the returns to agriculture are often low or negative, and thus some form of financing to support this transition is necessary. Their capacity to make the required adjustments depends on the existence of policies and investments to support farmers' access to credit, insurance, as well as on proper economic incentives. As reviewed by McCarthy et al. [40], As with any new technology, CSA options may be perceived as a risky investment, as farmers will need to learn new practices and typically do not have access to insurance. Credit constraints will affect adoption, especially when initial investment costs are high, given the evidence that the benefits of the practices are usually realized after around 4 years. 
Just how binding a cash constraint might be is obscured by the fact that many projects promoting CSA practices in fact provide the inputs such as seeds and seedlings for free, particularly in East and Southern Africa (Franzel et al., 2004); thus, it will be particularly important to determine conditions under which farmers access seeds/seedlings. Wealthier households with greater landholdings are more likely to adopt CSA practices such as agroforestry. This indicates that cash constraints and opportunity costs of land in the near term are likely to affect adoption decisions (Phiri et al., 2004; Kuntashula et al., 2002).

Effects of agricultural input and output markets on adoption of CSA: Agriculture is based on the use of natural resources supplemented with material and nonmaterial inputs to produce food and other products and services. The decisions farmers make about the type of technologies and practices they adopt is determined by the benefits and costs associated with it, which in turn is affected by the ability of producers to access input supply and output market chains. Improved market access that raises the returns to land and labor is therefore a critical force for the adoption of new climate-smart practices in agriculture. However, many smallholder farmers in vulnerable areas continue to face complex challenges in adoption of CSA options. There is still inadequate understanding of the market, policy and institutional failures that shape and structure farmer incentives and investment decisions [29].

Market failures in rural areas often arise out of asymmetric information, high transaction costs and imperfectly specified property rights. They are more pronounced in areas with underdeveloped road and communication networks and other market infrastructure. Under these circumstances, households tend to withdraw from markets and focus predominantly on subsistence production when food security through markets is not assured (de Janvry et al., 1991). Addressing these overlapping constraints requires innovative institutional arrangements and partnerships that improve local availability and utilization of CSA options and effective market linkages that offer more stable and better prices to producers. Farmer organizations have the potential to mitigate the effects of imperfect markets by enabling contractual links to input and output markets and promoting economic coordination in liberalized markets, hence leveraging market functions for smallholder farmers [41]. This can be expected to stimulate adoption of CSA options, which in turn drives the process of commercialization in rural areas.

Realizing the adoption potential of CSA practices will, however, depend on the ability to convey market information, coordinate production and marketing functions, define and enforce property rights and contracts and, more critically, mobilize producers to participate in markets and enhance the competitiveness of agroenterprises. This suggests that institutions provide multiple functions to markets. They transmit information, mediate transactions, facilitate the transfer and enforcement of property rights and contracts, and manage the degree of competition; thus, providing alternative mechanisms through which market failures in rural areas can be remedied [41].

Effects of credit facilities on adoption of CSA: Credit service is an important factor that influences adoption of agricultural technologies, especially for poor farmers who often have limited financial resources for purchasing agricultural inputs and implements [4].

Effects of Other Factors on CSA: Teklewold et al. (2013), (Wollni et al. 2010) as well as D'Souza et al. (1993) have used the number of CSA practices that a household practices as a measure for level of adoption of CSA practices. Teklewold et al. (2013) and Wollni et al. (2010) noted that equal probability of adoption for all CSA technologies, but in reality, adoption of the second or more technologies are conditioned by adoption of the first technology. So, the level of adoption of many CSA practices depends on adoption of first CSA technology. The model results indicate that the probability of adoption of more than two strategies was negatively affected by age of household head, total land area owned, petty trading and formal employments were found to reduce the probability of adopting more than two CSA strategies.

As identified by Teklewold et al. (2013) Farmers who reported observing changes in moisture levels in their areas for the 20-year period prior to the survey were found to have lower probability of adopting four CSA strategies as compared to those who reported not observing any changes in moisture in the same time period. Paradoxically, household income was found not to affect number of CSA strategies adopted.

Socio-economic characteristics of farmers, bio-physical environment of a particular location, and the attributes of new technologies can influence extent of adoption of CSA technologies such as [28]. The identification, prioritization and promotion of available CSA technologies considering local climatic risks and demand for technology are major challenges for scaling out CSA in diverse agro-ecological zones.

Basically, theidentification and prioritization ofCSA technologies support climate change adaptation planning in agriculture by designing an investment portfolio across various agro-ecological zones. When designing CSA implementation strategies at the farm level, one must consider adaptation options that are well evaluated and prioritized by local farmers in relation to prominent climatic risks in that location [38]. Despite the importance of prioritization of CSA technologies at farm level, existing climate change adaptation programmes lack such information for better adaptation planning. Evidences on farmers' prioritization can support key stakeholders make informed decisions that are in line with government policies and institutional arrangements.

Studies of farm-level adaptation that make use of household data sets confirm that farmers respond not only to climate stimuli but to a number of other factors as well (Maddison, 2007; Nhemachena and Hassan, 2007). Farm-level changes that might be expected given a certain climate signal may not actually occur 
due to other intervening factors, such as human capital (e.g. level of education, age, ethnicity, gender), economic conditions (e.g. relative prices, input and output market development, credit availability) and the policy environment [42]. The nature of farmers' responses to climate change and variability also depends on the socio-economic position of the household. Poor farmers are likely to take measures to ensure their survival, while wealthier farmers make decisions to maximize profits [43]. Climate change is thus expected to affect different segments of the rural population differently. At the same time heterogeneous responses to changing climate can be expected, based on differences in the socio-economic characteristics of different groups of people and localities (i.e. household resource endowments, poverty levels, livelihood coping strategies and infrastructure status). As reviewed by McCarthy et al. [40], the adoption of CSA options is also constrained by a lack of tenure security, which may affect farmers' incentives to adopt because of the time delay in enjoying the benefits from CSA and farmers' limited access to finance and insurance. CSA practices may increase labor requirements for weeding when implemented without herbicides, as is the case for most smallholders. Therefore, labor constraints may be binding for households without access to herbicides and enough labor. Although there is no conclusive evidence in the literature, agro-ecological constraints such as soils (e.g. drainage capacity) and climate (e.g. semi-arid regions with termites) are also likely to affect adoption. In addition to traditional constraints, for some CSA practices, competition for crop residues from livestock, which traditionally graze freely on harvested fields in most parts of Africa, is likely to decrease incentives for adoption in regions where livestock rearing is an important livelihood diversification strategy.

As reported by FAO, farmer adaptation to climate change requires rural communities to have access to better information, inputs such as fertilizer, machinery and a diverse set of seeds and breeds. Increasing the returns and benefits that agricultural producers derive from their production systems is an essential component of CSA and therefore also requires well-functioning and accessible output markets [44-49].

\section{Conclusion and Summary}

There are still about 800 million undernourished and 1 billion malnourished people in the world. At the same time, more than 1.4 billion adults are overweight and $1 / 3$ of all food produced is wasted. Before 2050, the global population is expected to swell to more than 9.7 billion people and it is estimated we will require $60 \%$ more food production by 2050 (World Agriculture towards $2030 / 2050$ ). Agriculture is uniquely placed to propel people out of poverty [50-54]. Agricultural growth is often the most effective and equitable strategy for both reducing poverty and increasing food security. The FAO defines climate-smart agriculture (CSA) as "agriculture that sustainably increases agricultural productivity, enhances resilience (adaptation) [of agricultural and food security systems to climate change at multiple levels], reduces/removes greenhouse gas/GHGs (mitigation) where possible, and enhances achievement of national food security and development goals.
Climate change alters agricultural production and food systems, and thus the approach to transforming agricultural systems to support global food security and poverty reduction. Climate change introduces greater uncertainty and risk among farmers and policymakers but need not lead to analysis paralysis. An integrated, evidence-based and transformative approach to addressing food and climate security at all levels requires coordinated actions from the global to local levels, from research to policies and investments, and across private, public and civil society sectors to achieve the scale and rate of change required. With the right practices, policies and investments, the agriculture sector can move onto CSA pathways, resulting in decreased food insecurity and poverty in the short term while contributing to reducing climate change as a threat to food security over the longer term. Even if the principal goal of CSA is food security and sustainable agriculture development, the adoption of this approach can be constrained by the lack of information, Finance and insurance, lack of enough agricultural inputs and shortages of credit facility in Developing country specially SSA [51-59]. In general, on the basis of paper we can conclude that agriculture practices should be smart and environment friendly. So that farmers should have ability to adapt climate change. Agriculture is considered to be "climate-smart" when it contributes to increasing food security, adaptation and mitigation in a sustainable way.

\section{Acknowledgement}

None.

\section{Conflict of Interest}

No conflict of interest.

\section{References}

1. AGRA (2017) Africa Agriculture Status Report: The Business of Smallholder Agriculture in Sub-Saharan Africa (Issue 5). In: Nairobi, Kenya (Eds.): Alliance for a Green Revolution in Africa (AGRA).

2. TS Jayne, Jordan Champerlin, Derek D Headey (2014) Land pressures, the evolution of farming systems, and development strategies in Africa: Food Policy. Elsevier.

3. IPCC (2007b) Climate Change 2007: mitigation. In: Metz B, Davidson OR, Bosch PR, Dave R, Meyer LA (Eds.), Cambridge University Press, USA.

4. FAO (2016) Ethiopia Climate-Smart Agriculture Scoping Study. In: Jirata M, Grey S, Kilawe E (Eds.), Ethiopia.

5. IPCC (2007) Summary for policymakers', Climate Change 2007: The Physical Science Basis' Contribution of Working Group I to the Fourth Assessment Report of the Intergovernmental Panel on Climate Change. In: Solomon S, Qin D, Manning M, Chen Z, Marquis M, et al. (Eds.), Cambridge University Press, UK, pp: 43.

6. Lipper L, Thornton P, Campbell BM, Torquebiau EF (2014) Climate-Smart Agriculture for food security. Nature Climate Change 4: 1068-1072.

7. OECD \& FAO (2010) Agricultural outlook 2010-2019.

8. Alexadratos N, Bruinsma J (2012) The 2012 revision. In: Alexadratos N, Bruinsma J (Eds.) Food and agriculture Organizations of the united nations, Italy, pp: 12

9. FAO (2011c) Energy-smart food for people and climate. Issue brief, Rome.

10. Branca GN, Mc Carthy, et al. (2011) Climate-smart Agriculture: A Synthesis of Empirical Evidence of Food Security and Mitigation Benefits from Improved Cropland Management. Working paper, Rome, FAO. 
11. FAO (1996) Spending adaptation money wisely, Centre for Climate Change Economics and Policy In: Fankhauser S, Burton (Eds.), Rome Declaration on World Food Security and World Food Summit Plan of Action, Rome, FAO.

12. Stamoulis K, A Zezza (2003) A Conceptual Framework for National Agricultural, Rural Development, and Food Security Strategies and Policies. ESA Working Paper No. 03-17. Rome, FAO.

13. OECD-DAC (2011) Tracking aid in support of climate change mitigation and adaptation in developing countries. Retrieved 10 December 2019.

14. World Bank (2010a) Economics of Adaptation to Climate Change: Synthesis Report. Washington DC, The World Bank.

15. Adger WN, Brooks N, Kelly M, Bentham G, Agnew M, et al. (2004) New Indicators of Vulnerability and Adaptive Capacity. Technical Report 7, Tyndall Centre for Climate Change Research, pp: 102

16.(2009) Organization for Economic Co-operation and Development (OECD) Managing risk in agriculture: a holistic approach. Paris.

17. Intergovernmental Panel on Climate Change (IPCC) (2007a) Climate change 2007: impacts, adaptation and vulnerability. IN: Parry ML, Canziani OF, Palutikof JP, Van Der Linder PJ, Hanson CE (Eds.), Cambridge University Press, UK, pp: 869-883.

18. Swanson DA Venema, HD Hiley J, Grosshans R (2007) Indicators of Adaptive Capacity to Climate Change for Agriculture in the Prairie Region of Canada: An analysis based on Statistics Canada's Census of Agriculture. International Institute for Sustainable Development and the Prairie Farm Rehabilitation Administration. Winnipeg, Canada.

19. FAO (2009a) The state of food and agriculture: livestock in the balance. Rome.

20. Brown J, Cantore N (2010) Climate financing and Development Friends or foes? Paper commissioned by The ONE Campaign. Overseas Development Institute, London.

21. Mc Gray HA Hammill, et al. (2007) Weathering the Storm, Options for Framing Adaptation and Development. Washington DC, World Resources Institute.

22. Olhoff A, C Schaer (2010) Screening Tools and Guidelines to Support the Mainstraeming of Climate Change Adaptation into Development Assistance. A Stocktaking Report. New York, UNDP.

23. IPCC (2001) The scientific basis, contribution of working group I to the third assessment report of the intergovernmental panel on climate change. In: Houghton JT, Ding Y, Griggs DJ, Noguer M, Van Der Linden, et al. (Eds.), Cambridge University Press, UK, pp: 881-842.

24. Bryant RC, Smit B, Brklacich M, Johnston RT, Smithers J, et al. (2000) Adaptation in Canadian agriculture to climatic variability and change. Climatic Change 45(1): 181-201.

25. Caldeira KM, Granger Morgan, et al. (2004) A Portfolio of Carbon Management Options. The Global Carbon Cycle: Integrating Humans, Climate and the Natural World. In: Field CB, Raupach MR(Eds.), Island Press, Scope 62, USA

26. Smit B, McNabb D, Smithers J (1996) Agricultural adaptation to climatic variation. Climatic Change 33(1): 7-29.

27. FAO (2009b) Food security and agricultural mitigation in developing countries: options for capturing synergies. Rome.

28. Campbell BW, Mann, et al. (2011) Addressing Agriculture in Climate Change Negotiations: A Scoping Report, Meridian Institute, India.

29. CCAFS, FAO (2014) Climate Smart Agriculture: What is it? Why is it needed? In: Food and Agriculture Organization of United nations, Rome, Italy.

30. United Nations (2015) departments of Economics and social affairs population division 2015. World population prospects: The 2015 revision. Working paper No. ESA/P/WP.241. New york, NY. The departments of Economics and social affairs of the UN secretariat.

31. CCAFS (2013) Big facts on climate change, Agriculture and Food security. In: CGIAR Research program on climate change, Agriculture and Food security (CCAFS), Copenhagen, Denmark.
32. https://www.worldbank.org/en/results/2017/11/29/climate-smartagriculture

33. Grist N (2015) Topic Guide: Climate Change, Food Security and Agriculture. DFID, United Kingdom.

34. IPCC (2013) Summary for Policymakers', Climate Change 2014: Impacts, Adaptation, and Vulnerability. Part A: Global and Sectoral Aspects. Contribution of Working Group II to the Fifth Assessment Report of the Intergovernmental Panel on Climate Change. In: Field CB, Barros VR, Dokken DJ, Mach KJ, Mastrandrea, et al. (Eds.), Cambridge University Press, UK, pp: 1-32.

35. Lobell, D Schlenker W, Costa Roberts J (2011) Climate trends and global crop production since 1980. Science.

36. Knox J, Hess T, Daccache A, Wheeler T (2012) Climate change impacts on crop productivity in Africa and South Asia. Environmental research letters 7: 034032.

37. Ajayi OC, Akinnifesi FK, SileshiG, Chakeredza S (2007) Adoption of renewable soil fertility replenishment technologies in the southern African region: Lessons learnt and the way forward. Natural Resources Forum 31(4): 306-317.

38. FAO (2012a) Improving food systems for sustainable diets. Rome.

39. Hansen J, Baethgen W, Osgood D, Ceccato P, Ngugi RK (2007) Innovations in climate risk management: Protecting and building rural livelihoods in a variable and changing climate. Journal of Semi-Arid Tropical Agricultural Research 4(1).

40. Mc Carthy NL Lipper, G Branca (2011) Climate-Smart Agriculture: Smallholder Adoption and Implications for Climate Change Adaptation and Mitigation. MICCA Working paper, Nr. 4, Food and Agriculture Organization of the United Nations, Rome.

41. Shiferaw B, Hailemariam T (2007) Structure and functioning of chickpea markets in Ethiopia: Evidence based on analyses of value chains linking smallholders and markets. IPMS Working Paper 6, ILRI, Nairobi, Kenya.

42. Bradshaw B, Dolan H, Smit B (2004) Farm-level adaptation to climatic variability and change: crop diversification in the Canadian Prairies. Climatic Change 67(1): 119-141.

43. Belliveau S, Bradshaw B, Smit B, Reid S, Ramsey D, et al. (2006) Farmlevel adaptation to multiple risks: climate change and other concerns. Occasional Paper, Canada, pp: 27.

44. FAO (2012b) Stability of food security in a green economy environment. Rome.

45. Bharucha Z, Pretty J (2010) The roles and values of wild foods in agricultural systems. Philos Trans R Soc Lond B Biol Sci 365(1554): 2913-2926.

46. Burney JA, Davis SJ, Lobell DB (2010) Greenhouse gas mitigation by agricultural intensification. Proc Natl Acad Sci USA 107(26): 1205212057.

47. FAO (2010a) "Climate-smart" agriculture: policies, practices and financing for food security, adaptation and mitigation. Rome.

48. FAO (2010c) Promoting the growth and development of smallholder seed enterprises for food security crops, case studies from Brazil, Côte d'Ivoire and India. FAO Plant production and protection, pp: 201.

49. FAO (2010d) Biodiversity and sustainable diets: united against hunger. Rome.

50. FAO (2011a) Potential effects of climate change on crop pollination. In: Kjøhl M, Nielsen M, Stenseth NC (Eds.), Why Climate-smart agriculture, forestry and fisheries, Rome.

51. FAO (2011b) Save and grow: a policymaker's guide to the sustainable intensification of smallholder crop production. Rome.

52. FAO (2012c) Towards the future we want end hunger and make the transition to sustainable agricultural and food systems. Rome.

53. FAO (2012d) Greening the economy with agriculture. Rome.

54. FAO (2012e) AGA in Acton. Animal Production and Health. 
55.FAO (2012f) Voluntary guidelines on the responsible governance of tenure of land, fisheries and forests in the context of national food security.

56. OECD (2011) Joint working party on agriculture and the environment: a green growth strategy for food and agriculture. Paris.

57. Thornton P, Cramer L eds (2012) Impacts of climate change on the agricultural and aquatic systems and natural resources within the CGIAR's mandate. CCAFS Working Paper No. 23. CCAFS, Copenhagen, Denmark.
58. World Bank (2009) Morocco study on the impact of climate change on the agricultural sector: impact of climate change osn agricultural yields in Morocco. Washington DC, The World Bank.

59. Ziervogel, G Bithell, M Washington R, Downing T (2005) Agent-based social simulation: a method for assessing the impact of seasonal climate forecast applications among smallholder farmers. Agricultural Systems 83(1): 1-26. 